\title{
Sustainable Retail Banking and Asset Management: Lessons from Challenges Faced by Entrepreneurs in African Economies
}

\author{
Paul Stanford Kupakuwana \\ Strategy $\mathcal{E}$ Business Analysis, Leeds Metropolitan University, \\ Faculty of Business \& Law, The Rose Bowl, Leeds, \\ United Kingdom
}

\section{Introduction}

In today's global banking marketplace, the pressures challenging traditional business practices are many and varied. Competition is fierce, resulting in new opportunities and new risks for entreprenuers. Customers are becoming increasingly well informed and demanding, and the emergence of new financial service providers is transforming the banking industry. Meanwhile, deregulation and the effective disappearance of national boundaries are opening up greater opportunities and an increased portfolio of products and services. Some banks and asset management companies are rapidly identifying and exploiting opportunities. Such institutions meet the market demand by fast developing a new and inexpensive product.

The changing behaviour of customers is a critical consideration for banks. As a result, banks and asset management companies that fail to compete and innovate effectively across all areas may risk losing market share. Innovation in retail banking and asset management companies emphasizes more in organisational and process changes than in new product development in the traditional sense. Organizations that can provide a relatively faster service to customer requirements will benefit from a competitive advantage over those that do not. The need to maximise the opportunities in African economies requires banks and asset management companies to extend access to traditional services such as credit and savings. To service these needs, over the last few years there has been some proliferation of new financial institutions in some African states. It was necessary that these new financial institutions maintained trust in order to remain socially relevant.

\section{Purpose and significance of entrepreneurship to retail banking and asset management studies}

At the centre of entrepreneurship is the need to understand the inter-relationships between strategy and an organisation's business and environmental context, to mitigate associated risks, and to exploit opportunities for value creation effectively (Hamann et al, 2010). An understanding of these principles will help retail banks and asset management companies to identify strategic priorities for policy and action. It highlights the potential business benefits 
of a systematic and proactive approach to sustainability concerns. Once a retail bank or asset management company has identified the scope and drivers of sustainability, the next step is to understand how to define and implement a corresponding entrepreneurial strategy. A crucial aspect of this is authentic stakeholder engagement and effective cross-sector collaboration (Hamann et al, 2010).

After reading this chapter, you should be able to:

- Understand the complexities and opportunities relating to the adoption of a strategic, proactive approach to sustainable retail banking and asset management in entrepreneurship.

- Understand the debates surrounding the role of corporate governance in sustainable retail banking and asset management, including various related concepts such as corporate social responsibility and stakeholder engagement.

- Identify the key principles and themes associated with the sustainable retail bank and asset management company, with an emphasis on the link to core business.

- Understand the business case for the sustainable retail bank and asset management company, and identify the business-related risks and opportunities associated with diverse aspects of sustainable development, emphasising a strategic entrepreneurial approach.

- Appreciate the opportunities and complexities of adopting a strategic entrepreneurial approach to the sustainable retail bank and asset management company, be it at the level of a small enterprise or multi-national corporation.

The research focuses on risk managing at the firm level as well as performance and productivity improvement. The study draws from the competitive demands and operating realities facing the industry sectors as they pursue competitive excellence. Implications of these results to the study of the broader service sector are drawn, as well as how the collapsing banks (and the different factors behind) impact entrepreneurs or small-tomedium-enterprises (or sme's).

\section{Why did some African banks and asset management companies collapse in the last decade?}

There are four leading suspects. Impacts on banking and asset management can be traced through, inter alia, four broad channels:

- A plethora of deficiencies; and

- Corruption; and

- Corporate governance; and

- Macroeconomic climate.

This leads to a focus on the four main hypotheses that have been mooted. To confront these hypotheses, the author looks at the disaggregated historical data on the performance of retail banks and asset management companies within the last decade in select African countries in order to determine the extent to which this proxy for the four main hypotheses.

Hypothesis 1: "a plethora of deficiencies" effect caused the distress and/or collapse,

"The natural selection process" determines which member of the two sectors collapse and which ones survive and recover. 
Hypothesis 2: "the corruption" effect caused the distress and/or collapse,

Corruption permeates governments, commerce and society.

Hypothesis 3: "the corporate governance" effect caused the distress and/or collapse,

The central banks are effective in corporate governance practices.

Hypothesis 4: "the macroeconomic climate" effect caused the distress and/or collapse,

African banks are directly involved in the credit crunch.

A benchmark needs to establish "normal" in order to evaluate these hypotheses. To this end, the methodology adopted is that used guidance provided in the New Capital Accord, also known as Basel 2, which aligns economic principles of risk management with regulatory capital requirements (Hashagen, 2003; Lutz, 2000).

Each is addressed in turn, in the process considering the broader macroeconomic impacts, and concludes with some thoughts about what this means for Africa in light of the wider consequences for banking and asset management.

\section{Literature review}

Many banking crises have been reported around the world within the last few years. For example, more than 140 crises were reported since the 1970s (Reinhart and Rogoff, 2008, 2009: Laeven and Valencia, 2008, 2010). More recently, Reinhart and Rogoff $(2008,2009)$ reported only 121 banking crises since 1800s till 1970s. By failures to rollover debt during panics or rapid withdrawals of debt, and insolvency, these exogenous shocks introduce pressures on banks, and are associated with the banking system distress (Calomiris, 2008).

The collapse of Lehman Brothers in September 2008 is thought to have caused the global economic crisis known as the "Great Recession". Global credit markets froze affecting the letters of credit and other financial instruments that help grease the gears of international trade finance (Mora and Powers, 2009). There is a link between banking and credit problems as revealed by research on historical episodes. Evidence presented in this chapter suggests that decline in global trade finance had a major impact on banking and asset management in Africa. Banking failures not only hurt private investors but also cripple foreign enterprises in their capability to invest and to create new jobs (Lutz, 2000).

The systemic character of financial risks is exactly the normative reason why in banking, unlike in other branches of the economy, the management of economic risk is an issue concerning the state. Legalized duties to build up capital buffers for risk protection and sanctions in cases of rule violations are instruments to establish a regulatory, safety net (Lutz, 2000). Ultimately, the aim is to prevent situations in which the state and thereby its national central bank are forced to intervene as lender-of-last-resort, leaving the taxpayer burdened with the losses created by privately undertaken risks (Lutz, 2000; Goodhart et al., 1998; Herring and Litan, 1995). There have been calls in several quarters for the protection of small investors through a deposit insurance scheme. But critics have equally responded by saying that this might encourage failure in banking, a situation that the deposit insurance is supposed to mitigate. 
The Basel Accords created an international standard on banking regulations (Hashagen, 2003). Basel I was first enacted in the 1980s. Basel II, the second issue of the accords, set up capital and risk management requirements. Thus, banks holding riskier assets now have to have a relatively higher capital reserve than those keeping safer portfolios (SearchSecurity, 2008). Basel II became a worldwide regulation in 2006 (Hashagen, 2003). Basel II requires companies to publish details of risk management practices and risky investments. Three essential requirements of Basel II are (SearchSecurity, 2008):

- Mandating that capital allocations by institutional managers is more risk sensitive.

- Separating operational risks from credit risks and measuring both.

- Reducing the scope of regulatory arbitrage by aligning the economic risk with regulatory assessment.

Basel II resulted in the emergence of a number of strategies which have allowed some banks to make risky investments, such as moving higher risks assets to unregulated parts of holding companies, the subprime mortgage market, and transferring the risk to investors by securitization (SearchSecurity, 2008). More important, however, are the wide range of risk management challenges and business implications that Basel II triggered for banks, their non-bank competitors, rating agencies, regulators, customers and, ultimately, the global capital markets. For example, (Hashagen, 2003):

- $\quad$ Banks are required to implement an organisation-wide risk management framework.

- Non-banks are not affected by Basel II but may want to draw important lessons as it is a competitive benchmark.

- Bank clients will need to collect and disclose new information - and likely will face new risk structures as a result of increased transparency.

- Rating agencies became visible under Basel II and thus could experience new competition.

- Regulators are asked to provide a level playing field as the Basel Committee's recommendations are implemented by legislatures in various countries.

- The global banks could experience extended trends towards securitization as financial institutions adapt to Basel II requirements.

Implementation of Basel II is a highly complex project (Hashagen, 2003). During a financial crisis, uncertainty is high, liquidity and trust are low, firms and banks rationalise by limiting their exposure to foreign banks and firms (Bernham and Martin, 2010).

\section{Case studies}

In most of the banking and asset management crises scrutinised around the world, there appears to emerge a number of common causal factors for entrepreneurial challenges. These studies of failed banking systems routinely point to explicit or implicit causes, and this study is no exception.

\section{Egypt}

The banking sector in Egypt witnessed many shocks over the last decade. The banking policies were put to the test and in most cases they proved rather successful (Business Today, 2011). The Egyptian banking sector was however subject to major reforms. The 
Central Bank of Egypt (CBE) tightly oversaw the sector's lending procedures and improved the management of the exchange rate policy. An interbank foreign exchange market was developed by the central bank, and this kept the black currency traders at bay. After being characterised as fragmented and fragile, Egyptian banking was transformed into a more robust and solid sector (Business Today, 2011). The government assisted in the cleaning of the banks' balance sheets by selling its equities to foreign-led acquisitions. Privatisations and consolidations reduced the number of banks from 57 in 2004 to 39 in late 2009 (Business Today, 2011).

Egypt's banking sectors' avoidance of risky derivatives transactions and short selling spared the negative effects of the global financial crisis of 2008-2009. The strictness of the central bank caused the banks to maintain enough liquidity reserves and healthy ratios, which allowed them to weather the storm. The central bank controlled the outflow of liquidity by panicking depositors, and not all bank branches were opened during the same time (Business Today, 2011). The reserves helped the banks to honour all transactions. Foreign currency reserves also played a vital role in supporting the economy, and in maintaining the exchange rate at an acceptable level as the central bank intervened by selling some of its dollars (Business Today, 2011).

The central bank made life easier for dealers by offering them a series of repurchase agreements called 'repos'. Such transactions work by having the central bank accepts money market securities from the banks and oblige them to buy back the securities at the sale price plus interest (Business Today, 2011).

\section{Kenya}

In 1986, the first bank crash occurred when poorly capitalized banks went belly up without the Central Bank of Kenya's (CBK) intervention. One banker ran away to Scandinavia and had his property inexplicably sequestered by government (Maiko, 2003). The next crash was in 1992. This was related to the elections which caused politically linked banks to obtain money from the CBK using devious schemes. Six banks associated with some Asian businessmen were put in liquidation in 1993 (Maiko, 2003). The next one followed the 1997 elections, in 1998. Shareholders and politicians stripped clean banks leaving them on the brink. Disaster struck when the National Bank was made bankrupt putting at the tender mercy of the liquidator before the government injected capital and the National Social Security Fund (NSSF). The Euro Bank went down after the exposure of a scandal involving the disappearance from the institution of US 3.4 million of NSSF money (Maiko, 2003).

The collapse of Trust bank in 2001 threatened to tilt the balance against small banks in the country (Maiko, 2003). On the other hand, the collapse of the Euro Bank with billions of shillings of parastatal money sparked off another flight to safety. The result was a loss of confidence in the regulatory role of the Central Bank of Kenya (CBK). In 2002, the cyclical banking crisis phenomenon benefited large transnational banks, such as subsidiaries of UK banks Standard Chartered and Barclays and the 35 per cent state-owned Kenya Commercial. Their coffers swelled whereas Asian and African-owned banks were on the fringes (Maiko, 2003). By March 2003, 77.5 per cent of the industry's US $\$ 46$ billion deposit liabilities was in the coffers of the ten largest banks, against a background of commercial banks dominance following the collapse of indigenous non-bank institutions in the mid 1980s (Maiko, 2003). 
In 2003, profit sharing in the industry took a similar pattern, only that Barclays and Standard took a disproportionately bigger share compared to Kenya Commercial, which was managed badly then. There were ten commercial banks, two mortgage firms, three nonbanks and four building societies in the country (Maiko, 2003). Structural asymmetry in the system was brought by insecurity in small banks. Small banks were forced to pay relatively high deposit interest rates. Large banks were deemed insensitive to customers, levying all manner of charges and penalties on both deposits and lending. The Central Bank (Amendment) Act 2000, popularly known as the Donde Act, helped to regulate the lending rate by controlling both supply and demand prices (Maiko, 2003).

The ill-fated Euro Bank was in the business of holding and not trading state money. Its dud assets piled at 260 per cent of their equity fund size. Ninety-two per cent of the nonperforming debts were taken out by state firms' heads and politicians. These people pumped government funds into the dying bank. It is alleged that the bank was involved in money laundering. Its political connections are said to have helped to keep it open (Maiko, 2003). Some banks in Kenya collapsed when power changed hands, and the protective veil was withdrawn.

\section{Nigeria}

The emergence of indigenous banks in Nigeria almost immediately introduced collapse of deposit taking institutions. Twenty-one out of twenty-five indigenous banks in the country collapsed between 1947 and 1952 (Financial Nigeria, 2006). Capital injection into the banks in 2007 through public offers and IPOs alone resulted in mega banking in Nigeria. It is thought that the regulatory gap before the establishment of the Central Bank of Nigeria (CBN) may have been responsible for the earliest episode of collapse of banks in Nigeria. Between 1920 and 1930s, the earliest indigenous banks rapidly multiplied, whereas in 1954 that was the launch of the first banking regulatory instrument. At that time, skilled and experienced bankers and asset managers were scarce. Indigenous banks were characterised with insider loan abuses and poor capitalization. Thus, their performance standards were below par with competing foreign banks (Financial Nigeria, 2006). Some small and midsized companies and some fake companies received hefty loans, but before the banks went bust. Some politicians also made the A-list of bank debtors (Murphy, 2009). Some executives influenced share prices by conspiring with stockbrokers. Some CEOs who were charged with fraud went on the run and were wanted by Interpol (Murphy, 2009).

In 1960, over $95 \%$ of the licensed indigenous banks were liquidated by independence. Government replaced this model of bank ownership with government ownership. The argument was that banks are considered as development agents, and hence they became an integral part of Nigeria's economic nationalism (Financial Nigeria, 2006). The federal government bought controlling stakes in the foreign banks. State governments were encouraged to start their own banks (Financial Nigeria, 2006). The country was returned to the private ownership model when the economy was liberalized in the mid-eighties. Banking licenses were issued to over 80 local entrepreneurs. This was the era which resulted in banking distress and failures with depositors losing their money (Financial Nigeria, 2006).

There was a combined weakness in that the regulatory regime was weak and that the banks were too many to be effectively managed by regulators. There were gross insider abuses, financial recklessness, and outright criminality by a young generation of bank directors and bankers. Hence, banks became poorly capitalized. There was a skill gap in managing risks in 
such a turbulent macroeconomic climate characterised by structural change driven by controversial policies.

Before July 6, 2004, 25 banks and those with interconnected liabilities almost collapsed (Financial Nigeria, 2006). Following consolidation in 2005, The Nigerian banking sector, however, took off to become the largest in sub-Saharan Africa outside South Africa. Nigerian banks aggressively expanded in Africa and Europe (Business Monitor International Ltd, 2009). The reform that began in 2009 is paying off and that the country's 24 banks are healthier (Daily Trust, 2011).

\section{South Africa}

South Africa's economy is very vulnerable to what happens on Wall Street. South Africa has a highly concentrated banking sector. There was legitimate fear of severe spillover effects of the escalating inflation and banking sector crisis in Zimbabwe. The escalating crisis in Zimbabwe's banking sector was a cause of concern to three investing South African banks that had majority shares in some Zimbabwean banks; that was Absa, Standard Bank and Nedcor. Standard Bank owned Stanbic Bank Zimbabwe. Absa owned 26\% of Commercial Bank of Zimbabwe (CBZ). Nedbank Africa owned 39\% of the Merchant Bank of Central Africa (MBCA) based in Zimbabwe, while Old Mutual Zimbabwe owned just under $23 \%$. Standard, Absa and Nedcor, kept an eye on unfolding crisis for signs of systemic risk.

The banks that failed during the period commencing from 1994 to date included Prima Bank, Sechold Bank, African Bank, Community Bank, Islamic Bank, FBC Fidelity Bank, New Republic Bank, Regal Treasury, Saambou and BoE (Makhubela, 2006). Four big banks exposed to housing credit included ABSA and FNB. The introduction of the Financial Intelligence Centre Act 38 of 2001 (FICA) knocked the wind out of the housing market.

The African Bank Limited set up at the height of apartheid in the 1970s assisted mostly black investors. It was the first fully black-owned bank to be put under receivership in 1995 after 20 -years in operation. Its closure was a blow to black economic empowerment (Chicago Tribune, 1995). Thereafter, a number of most troubling things happened in South Africa, which showed that the country's economic base was slowly falling apart and crumbling. One example is the accidental run on SAAMBOU bank due to some troubling news reports. As a consequence, one billion rand was withdrawn, and the bank put under curatorship, and all withdrawals stopped (Lamprecht, 2002).

\section{Swaziland}

The 2008 Lehman Brothers collapse in the United States is alleged to have triggered a worldwide banking crisis including in Swaziland (Swaziland Commentary, 2010). The IMF reported that Swaziland had the worst economy then in the whole of sub-Saharan Africa and that the economy was in a mess long before 2008 (Swaziland Commentary, 2010). Hence, the major economic crisis that Swaziland faced in the last decade was not connected to the Lehman Brothers collapse. Swaziland's economy stagnated over the last decade while that of the rest of sub-Saharan Africa grew (Swaziland Commentary, 2010).The major contributor to the stagnant Swazi economy was its financial sector, which despite being in a healthy operational condition, had however taken backward steps in the past decade (Swaziland Commentary, 2010). Swaziland's real per capita GDP growth declined from an 
annual rate of two and a half percent during 1980-94 to 0.7 percent since then compared to the average one and a half percent annually for sub-Saharan Africa since 1995 and in the lower-middle income countries, growth averaged 7 and a half percent (Swaziland Commentary, 2010).

Swaziland's financial system became shallower instead of deepening - that is, the more access individuals and businesses had to varied financial services, the better it would have equipped Swaziland to mobilise resources towards growth and the reduction of poverty and income inequality (Swaziland Commentary, 2010). Since 1995, there was a decline in private sector lending, bank deposits, and money supply as a percentage of GDP. Swaziland's reported cases of HIV/AIDS are so far the highest in the world (Swaziland Commentary, 2010). It is believed that some important linkages between the financial sector and the real economy in Swaziland do explain the country's poor performance (Swaziland Commentary, 2010). For instance, the country mobilises a small amount of domestic savings (8 percent of GDP) to finance investment, A fall in foreign savings was witnessed since the 1980s and 1990s, and so were annual investment rates which declined far below other low-income countries in the region from 25 to 19 percent of GDP for the period 1981-94. The government spent more than it collected in revenues and was saddled with a huge civil service wage bill that, together with poor projects selection and appraisals, curtailed growth.

The commercial banking system catered for approximately 38 percent of the population who had access to a bank account, and concentrated on export financing. Yet, the export sector failed to promote effectively employment and growth. Swaziland had no public credit registry except private credit bureaus which covered only 38 percent of the population. The weak investment climate pushed up the cost of capital and reduced the rate of return investors sought. The inadequate regulation and supervision of nonbank financial institutions (NBFIs) rendered the financial sector more vulnerable. Savings and credit cooperatives (SCCOs) emerged to cater for the financial needs of the significant Swazis who had been abandoned by the commercial banking sector. Some borrowers failed to secure loans due to a lack of access to collateral. Approximately 60 percent of the land is held in public trust and could not be used by farmers as collateral to secure loans to facilitate the achievement of higher agricultural yields. Instead, people are limited to accumulating savings in traditional assets such as livestock (Swaziland Commentary, 2010).

\section{Zimbabwe}

The first report of a collapsed bank in Zimbabwe was that of Roger Boka's United Merchant Bank in 1998. UNIBANK followed in year 2000. From then on, the financial system began to suffer serious tremors. The climax came in 2003 after the failure of ENG Asset Management that triggered a wholesale run on banks. In a space of six months, seven banks closed their doors. Locally-owned banks and asset management companies battled for survival, with some closing, as the Reserve Bank of Zimbabwe (RBZ) cracked down on institutions engaged in shady dealings (Muleya, 2008; Mpofu and Nyakazeya, 2011; Business Reporter, 2011). Such institutions included the United Merchant Bank, First National Building Society, Unibank, Trust Banking Corporation, ENG Capital, First Mutual Asset Management Company, Century Discount House, Intermarket Holdings' subsidiaries - the Discount House, Intermarket Building Society, and the Banking Corporation. Some banks experienced liquidity problems arising from their involvement in speculative and non-core 
activities (Muleya, 2008; Chimhangwa, 2011; Mambondiani, 2011; Business Reporter, 2011). The move to close some bank by the central banks was meant to protect depositors' funds. The central bank appointed administrators to run some of these troubled banks in a bid to prevent a sector-wide contagion (Mpofu and Nyakazeya, 2011; Business Reporter, 2011).

Corruption and mismanagement took place on a staggering scale. Some banks and asset management companies closed as a result of a domino effect resulting from exposure, to varying extents, to those that had closed before them. A typical example was the exposure due to the closure of ENG Capital where Trust Banking Corporation, Century Bank, Metropolitan Bank and First Mutual Insurance group were directly exposed to the ENG's financial flu (Mambondiani, 2011). The ENG Asset Management Directors diverted invested clients' money to buying properties and luxury vehicles in Zimbabwe and from overseas. The fraud case sparked a crisis that saw a run on deposits by panicky investors (Mambondiani, 2011; Mpofu and Nyakazeya, 2011; Business Reporter, 2011).

Prior to the collapse of several indigenous banks and asset management companies, Zimbabwe had seventeen commercial banks with assets amounting to about 3.522 million US dollars. Average liquidity ratio as at September 30, 2004 was 58.2 percent. About twothirds of these banks had been established in the past decade when the government liberalized the sector in the 1990s. Skewed government policies since independence from Britain in 1980 had led to huge unemployment, soaring inflation, and acute shortages of foreign exchange, food, and fuel.

By January 2004, seven banks, namely Trust Bank, Time Bank of Zimbabwe, Metropolitan Bank, Century Bank, Royal Bank, Barbican Bank, including the Agricultural Bank of Zimbabwe (AgriBank) owned by the government, had been excluded from the daily clearing because they did not have the necessary cash to pay other banks. AgriBank lent an undisclosed amount to new farmers. These farmers were given land confiscated from white commercial farmers, and had not managed to grow adequate crops to repay their loans.

Most banks that had low liquidity levels were left exposed and scurrying for financial cover after the central bank demanded urgent recapitalization. In addition, the central bank expected the banks to observe the New Capital Accord known as Basel 2. This seeks to align regulatory capital with risk management. In November 2003, liquidity deficiencies in frailer banks were revealed by the real-time settlement system for interbank loans. Some banks had to sell their foreign currency reserves and properties in order to raise their capital levels and improve their liquidity. The tightening of the lending between the central bank and commercial banks led to an increase in interbank lending interest rates. This filtered through to an increase in interest rates charges for consumer loans.

In January 2004, the central bank in Zimbabwe began foreign currency auctions in what it said was a move to end black market trading. The central bank ordered banks to ensure they could meet their commitments to depositors. This resulted in some banks disposing of hoarded foreign currency, luxury vehicles, houses and jewellery. The short-term result was that the black market for U.S. dollars dropped. Several leading exporters said this had affected their ability to do business, because they had only managed to stay afloat by cashing foreign currency at the top rate.

Shocked cold by the closure of several banks, bankers called for an "amnesty" period from the central bank. They agreed that lessons had been learnt and that they now needed time to 
clean things up. However, it seemed bankers' pleas for a moratorium were unlikely to get a favourable ear. The central bank stated that Zimbabwe was over-banked, pledging to block fresh applications for banking licenses. The sweeping clean-up drive by the central bank sent business magnates fleeing abroad to escape imprisonment (Nyakazeya, 2011).

In December 2003, Zimbabwe's central bank promoted greater accountability and transparency by announcing that no management position will be held by a bank owner. Bank management, the board and/or its chair, was not to have a shareholder with $10 \%$ or more shares. Prior to this announcement, and the clampdown by the central bank, Zimbabwe's 17 banks were reported to have had some managers who were also major shareholders (Mpofu and Nyakazeya, 2011; Business Reporter, 2010).

Thus, Zimbabwe's new banks faced failure due to irresponsible practices including mismanagement and structural ownership weaknesses which led to liquidity and solvency deficiencies and saw a run on deposits by panicking depositors (Muleya, 2008; Chimhangwa, 2011; Mambondiani, 2011; Business Reporter, 2011).

\section{Diagnosing entrepreneurial challenge drivers in the last decade}

The author evaluates four hypotheses on the causes of distress and/or collapses:

Hypothesis 1: "A plethora of deficiencies" effect caused the distress and/or collapse,

The author found strong evidence in favour of the Hypothesis 1. Darwin's (1859) natural selection theory is applied here to this particular retail banking and asset management situation. According to Darwin's theory, the natural selection process determines which members of species survive and reproduce, and which ones die prematurely. Hence the surveys show:

- Major commercial banks and other financial houses faced critical liquidity crisis largely caused by unlawful speculative investments which threatened to ruin the stricken institutions (Maiko, 2003; Muleya, 2008; Chimhangwa, 2011; Mambondiani, 2011; Business Reporter, 2011).

- The minimum capital adequacy threshold requirement was not complied with in a majority of cases, i.e undercapitalisation (Chimhangwa, 2011).

- There was a high level of non-performing loans.

- Big clients moved their deposits from some recently established commercial banks to the traditional banks such as Standard Chartered and Barclays (i.e. flight to safety).

- These long-established traditional banks turned down cheques issued by banks suspected to be under investigation.

- Many retailers refused to accept cheques or guarantees from banks suspected to be under investigation.

Hypothesis 2: "the corruption" effect caused the distress and/or collapse,

The author found strong evidence in favour of the Hypothesis 2. Corruption permeated governments, commerce and society. Corruption is a stumbling block to development and has a bearing on economic fundamentals. As the African countries' economies struggle, most peoples' means correspondingly dwindle, and hence the temptation to become corrupted in order to survive. Surveys show: 
- $\quad$ Special Purpose Vehicles (SPV) were used to circumvent regulations and to engage in non-core activities including gold, grain and fuel trading, stock of bricks, luxury vehicles, and houses contrary to the Banking Act (Sandu, 2011).

- Depositors' funds were siphoned through related party loans (Sandu, 2011).

- Internal controls virtually collapsed allowing unauthorised transactions to occur (Sandu, 2011).

- Some of the group's shareholding structures camouflaged the true identity of the beneficiary shareholders (Sandu, 2011).

- Non-performing insider loans were issued to sister and sinister companies (Business Reporter, 2010).

- Trusts were designed to camouflage reality on the ground, their purpose, and personalities behind them.

- Investors' money was used to buy fixed assets that could not be readily converted into cash when the investors' funds reached maturity, leaving banks unable to meet their financial obligations.

- The shareholding structure of some banks hindered effective regulation and supervision as it facilitated owner-managers of these banks to masquerade as nonexecutive directors (Business Reporter, 2010; Muleya, 2011).

- Some banks were conduits for money laundering while some engaged in shady dealings (Maiko, 2003).

- Some bank's political connections helped to keep them open, whereas others collapsed when the protective veil was withdrawn when power changed hands (Maiko, 2003).

Hypothesis 3: "the corporate governance" effect caused the distress and/or collapse,

The author found strong evidence in favour of the Hypothesis 3. This exercise suggests further evidence of slack in corporate governance practices at the time across the banking and asset management sectors of most of the African countries under consideration (Sandu, 2011). In some cases, internal audit failed to discharge its statutory obligations. Surveys show:

- Foreign-owned banks were targeted by the indigenisation act and required to transfer majority shareholding to local blacks under a controversial empowerment policy (e.g. Barclays Bank and Standard Chartered Banks in Zimbabwe) (Chinaka, 2011).

- Because of the absence of tight oversight, some banks were able to make seemingly small gambles, and these banks decisions routinely resulted in losses of substantial sums.

- Some banks short-circuited internal control/audit and normal accounting safeguards. In effect, they were able to operate with no proper supervision from central banks - and hence were able temporarily to hide their losses (Sandu, 2011).

- Some asset management companies were of an underground nature as they had neither physical addresses nor working contact phone numbers.

- There were cases of violations of the Exchange Control Regulations.

- There were cases of violations of the Banking Act (Mpofu and Nyakazeya, 2011).

Hypothesis 4: "the macroeconomic climate" effect caused the distress and/or collapse,

The author found strong evidence in favour of the Hypothesis 4. The financial crisis was systemic. It sparked a credit crunch which was severe in some African countries and 
reduced the confidence of financial institutions. The severe economic crises were blamed on governments' mismanagement. It is believed that the growing turmoil in the banking sector followed the governments' new monetary policy announcements. Loose monetary policies left interest rates highly negative in real terms, intensified inflationary pressures, encouraged excessive borrowing, imposed a heavy tax on savers, and increased the vulnerability of the financial sectors. Surveys show:

- It is argued that African banks were not directly involved in the credit crunch due to Sub-Saharan Africa's low level of financial development (Bernham and Martin, 2010).

- It is argued that if the cost of such low development is that African exporters are very dependent on external trade finance, then the real cost of the global crisis on Africa may actually be higher (Bernham and Martin, 2010).

- It is argued that while African banks preferred not to buy "toxic" assets in order to provide for some shelter, the continent may have been hit harder by the trade transmission channel (Bernham and Martin, 2010).

- It is argued that trade collapse did hit hard African countries (Baldwin, 2009; Draper and Biacuana, 2009; Kandiero and Ndikumana, 2009).

- Part of the bank collapses can be accounted for by compositional effects and vertical linkages.

- Some institutions closed as a result of a domino effect resulting from exposure, to varying extents, to those that had closed before them.

- The adverse situation was a reflection of scarcity in the market, low level of economic activity and investor apathy (Robertson, 2011).

- Most of the money in banks was on call basis rather than fixed deposits. Banks could not lend money that urgently needed to be withdrawn (Robertson, 2011; Chimhangwa, 2011).

- The lack of investor interest naturally translated into money shortage in the banks resulting in high interest rate charges on loans (Robertson, 2011; Chimhangwa, 2011).

- Some banks were also being targeted by the indigenisation act (Chinaka, 2011; Chimhangwa, 2011).

\section{How much does each factor matter in entrepreneurship?}

One can test his/her thinking further and determine to what extent each effect accounts for the bank and asset management company collapses in the last decade. As it turns out, the corporate governance effect is by far the most important. This work suggests that because of the absence of tight oversight, some banks were able to make seemingly small gambles, and these banks' decisions routinely resulted in losses of large sums. This exercise suggests further evidence of slack in corporate governance practices at the time across the banking and asset management sectors of most of the African countries under consideration.

\section{Multilateral support efforts}

The central bank and the courts play an important role to ensure the protection of depositors' funds and to support entrepreneurs. Although banks were given a reprieve by the central banks to desist from the black market trading, the African states continued to pursue alleged offenders. The shocks of the credit crises spurred lawmakers to consider 
semi-nationalisation of some troubled banks. Western countries use nationalisation to propup banks during tough times in an emergency. Its use is to lend to businesses in order for them to restructure burdensome loans (Kim and Moore, 2009).

The less vulnerable large foreign-owned banks with strong controls and foreign shareholder support benefited from the crises as they continued to attract money. Panicked depositors shifted money to them. Some banks discussed consolidation and possible mergers. Thus, the foregoing is a clear testimony of the "survival of the fittest" banks and asset management companies through superior service quality delivery. First National Bank of South Africa has since bought the Swaziland Meridian BIAO operations. Standard Bank of South Africa (Stanbic) acquired Tanzania's Meridian BIAO. The Ghana Reinsurance Organisation (GRO) together with the Social Security and National Insurance Trust (SSNIT) announced a $\$ 7.2 \mathrm{~m}$ rescue package for the local Meridian BIAO.

A new African regional strategy was recently drawn out by the World Bank. This provides a vision for the next decade for the multilateral institution. The strategy was developed through the widespread consultations with representatives from the private sector, government, and civil society (The Standard, 2011).

\section{Overall conclusions and recommendations}

Prior to discussing possible implications of this study for entrepreneurs (or sme's), it is important to mention some caveats.

- First, the analysis focuses on randomly selected African countries whose data was readily available; hence these results are considered to be fairly representative of the entire African continent comprising of 54 countries.

- Second, crises are not the same, as some countries are hit harder. Poorer countries with less developed financial systems suffer more during financial crises, e.g. Zimbabwe (relatively less developed) vs. South Africa (relatively more developed). Deeper crises have more profound consequences.

- Third, the impacts of the macroeconomic climate on entrepreneurship will depend on the respective country's foreign exchange reserves, balance of payments position, and fiscal position (Draper and Biacuana, 2009).

The effect of the crisis is crucially dependent on the external demand conditions surrounding the crisis and the sectoral composition. Hence using a theory-based benchmark in the form of Basel 2, this chapter marshals the best available evidence on the causes of bank and asset management company distresses and/or collapses in the last decade within select African countries and explains how the collapsing banks (and the different factors behind) impact entrepreneurs (or sme's).

This research revealed a plethora of deficiencies within the banking and asset management companies which included inappropriate shareholding structure, inadequate capitalisation, systematic abuse of depositors' funds, disintegration of corporate governance structures, chronic liquidity and income generation challenges, greediness, high level of nonperforming insider and related-party exposures, gross violation of banking laws and regulations, inadequate regulation and oversight, as well as a weak and uncoordinated legal framework (Muleya, 2011; Mpofu and Nyakazeya, 2011; Business Reporter, 2010). 
The crisis impacts serve to reinforce the point of the integration of African economies into the global economy. Any major changes to global banking and asset management patterns that the crisis may engender are likely to substantially transform the African entrepreneurial structural features (Draper and Biacuana, 2009). Additional impacts are possible at policy level too (Draper and Biacuana, 2009). For banks and asset management companies to fully recover, policymakers should undertake the following measures in the spirit of entrepreneurship, amongst others:

- Management teams should understand fully the nature of the businesses they manage.

- Management needs to establish and communicate clearly responsibilities for each business activity.

- In order to exercise effective control, there should be a clear segregation of duties.

- There is a need to establish relevant internal and risk management controls for all business activities

- Management should ensure that significant weaknesses identified to them are resolved quickly.

- Industry regulators should continue to monitor corporate governance and regulatory compliance in banks (Business Reporter, 2010; Financial Nigeria, 2006).

- The central banks should develop capacities to govern the fiscal and monetary policy frameworks that will drive growth in economies (Financial Nigeria, 2006).

- Skill acquisition and development in information technology security and risk management is needed (Financial Nigeria, 2006).

- Banks need to strategise by mobilization of deposits for lesser dependence on the high interest rate public sector funds (Financial Nigeria, 2006).

- There is a need to regulate inter-bank lending in order to prevent the new mega banks apocalyptic multiple failures (Financial Nigeria, 2006).

The efforts of the central bank should be directed at containing the multiplier and domino effect (Muleya, 2011). The central banks should keep eye on the ball. At the end of the day, autonomy of the central banks will reassure the banking industry. The curatorship protects depositors, preserves the assets of banks, and protects the stability of the financial system using the law and market solutions (Muleya, 2011; Macheka, 2011). Thus, given all the necessary support, entrepreneurs (or sme's) are able to take advantage of emerging opportunities, explore and question the world around them, and also to embrace their passion.

\section{Acknowledgements}

We are like dwarfs on the shoulders of giants, so that we can see more than they, and things at a great distance, not by virtue of any sight on our part, or any physical distinction, but because we are carried high and raised up by their giant size. (Bernard of Chartres, 12th Century)

It is without some hesitation that I assent to Chartres' point of view. It is with great pleasure to recognise and thank my giants who have frequently carried me on their shoulders in diverse ways. I have had the great privilege of working with various teams over an extended period of time and learning from, and enjoying, the insights of highly diverse and 
challenging groups. Without their efforts, support and encouragement, I may well have fallen along the wayside and have found plenty of reasons to put other less academic distractions far higher on my list of priorities. They know who they are. Thank you all.

Lastly, a huge debt of thanks goes to my family, who have been amazing for their patience and unstinting belief, and are the ones who gave me the encouragement in the first place: I could not have done this chapter without you.

\section{Footnotes}

1. For a detailed description of BASEL II, see:

a. KPMG (2003). "Basel II: A Worldwide Challenge for the Banking Business", Financial Services, KPMG International, a Swiss non-operating association, Head of KPMG's Basel Initiative.

2. For a detailed description of banks performance evaluation, see:

a. Wirnkar, A.D. and Tanko M. (2008). “CAMEL(S) and bank performance evaluation: The way Forward", Electronic copy available at: http://ssrn.com/abstract=1150968. pp. 1-21.

b. Cicea, C. And Hincu, D. (2009). "Performance evaluation methods in commercial banks and associated risks for managing assets and liabilities", Academy of Economic Studies Bucharest, Romania, Communications of the IBIMA, Volume 7, ISSN: 1943-7765, pp. 97-101.

c. Hunjak, T. and Jakovcevic, D. (2001). "AHP based model for bank performance evaluation and rating", Proceedings - 6 $6^{\text {th }}$ ISAHP, Berne, Switzerland, August 2-4, pp. 149-157.

3. For a detailed description of the impact of the global economic crisis on Sub-Saharan Africa, see:

a. Arieff, A. et al. (2009). "The Global Economic Crisis: Impact on Sub-Saharan Africa and Global Policy Responses", Congressional Research Service, Report for Congress, 7-5700, www.crs.gov, R40778. August 25.

4. For a detailed description of distress classification measures in the banking sector, see:

a. Carapeto, M. et al. (2010). "Distress classification measures in the banking sector", European Financial Management Association (EFMA), Conference. Location: Aarhus, Denmark. January 14.

b. Demirguc-Kunt, A. et al. (2006). "Inside the crisis: An empirical analysis of banking systems in distress", Journal of International Money and Finance, 25, 702-718.

c. Poghosyan, T. Et al. (2009). “Distress in European banks: Ana analysis based on a new dataset", Paper provided by International Monetary Fund, Number 09/9, http://www.imf.org/external/pubs/ft/wp/2009/wp0909.pdf. 21 Jan.

\section{References}

Baldwin, Richard (ed.), The Great Trade Collapse: Causes, Consequences and Prospects, VoxEU.org, 27 November. 
Bernham, N. and Martin, P. (2010). The vulnerability of sub-Saharan African countries to financial crises: The case of trade, Sub-Saharan Africa and the great trade collapse: Research - based policy analysis and commentary from leading economists. VoxEU.org, 22 April.

Business Monitor International Ltd, (2009). "Nigerian Banking Sector On the Brink", Thursday, January 15, 2009, 6:15 pm, BST. www.riskwatchdog.com/print.php?pid $=644$.

Business Reporter, (2011). "Troubled RMB placed under curatorship", The Zimbabwe Situation, http://www.theindependent.co.zw/, Friday, 03 June 2011 00:00:00, and http://www.zimbabwesituation.com/jun4_2011.html. Accessed 08/06/2011.

Business Today, (2011). "A sector to bank on", Modern Egypt Info. July 18, http://www.modernegypt.info/online-newsroom/egypt-news-archive/a-sectorto-bank-... Accessed 22/07/2011.

Calomiris, C.W. (2008). "Banking Crisis", The National Bureau of Economic Research (NBER) Reporter: Research Summary, Number 4.

Chicago Tribune, (1995). "Black bank collapse: The collapse of South Africa's first fully black-owned bank", Evening Business, September 11,

Chimhangwa, K. (2011). "Zim banking sector struggles to survive", The Zimbabwe Situation, http://www.thestandard.co.zw/, Sunday, 01 May 15:52, and http://www.zimbabwesituation.com/may2_2011.html. Accessed 17/05/2011.

Chinaka, C. (2011). "Zimbabwe threatens foreign banks over empowerment", http://af.reuters.com/, Sun, May 15, 4:28 pm. GMT. and

http:/ / www.zimbabwesituation.com/may16_2011.html. Accessed 17/05/2011.

Daily Trust (2011). "Nigerian banks in fresh trouble", NigeriaIndependent.com, 27/04/2011 06:34:00

Darwin, C. (1959). On the Origin of Species by Means of Natural Selection, or, the Preservation of Favoured Races in the Struggle for Life. London: J. Murray.

Draper, P. and Biacuana, G. (2009). "Africa and the trade crisis", in Richard Baldwin (ed.), The Great Trade Collapse: Causes, Consequences and Prospects, VoxEU.org, 27 November.

Financial Nigeria, (2006). Banking and Finance: Histo - Regulatory Perspective of Bank Failures in Nigeria.

Gono, G. (2011a). "Reserve Bank of Zimbabwe (RBZ) should keep eye on the ball." http://www.theindependent.co.zw/. Thursday, 02 June, 19:53.

Gono, G. (2011b). Troubled Renaissance Merchant Bank (RMB) placed under curatorship. NEWZIMBABWE.COM: Published on: Friday, June 03, 11:00 AM GMT. http:/ / www.newzimbabwe.com/news/news.aspx?newsID=5266.

Goodhart, C. et al. (1998). Financial Regulation. Why, how and where now? London: Routledge.

Hamann, R., Kapelus, P. and Ndlovu, N. (2010). Sustainable Organisation, Strategic Management - Developing Sustainability in Southern Africa. Lynette Louw and Peter Venter, 2nd Edition, Oxford University Press, Southern Africa.

Hashagen, J. (2003). “Basel II: A Worldwide Challenge for the Banking Business”, Financial Services, KPMG International, a Swiss non-operating association, Head of KPMG's Basel Initiative.

Herring, R. J. and Litan, R. E. (1995). Financial Regulation in the Global Economy, Washington D.C. 
Kandiero, Tonia and Leonce Ndikumana (2009), "Supporting the World Trade Organisation Negotiations: Looking Beyond Market Access", in Richard Baldwin (ed.), The Great Trade Collapse: Causes, Consequences and Prospects, VoxEU.org, 27 November.

Kay, J. and Vickers, J. (1988). Regulatory Reform in Britain, in Economic Policy 7: 8, 285 - 351.

Kim, J.J. and Moore, H. (2009). "What if Uncle Sam takes over your bank?", The Wall Street Journal, WSJ.com, Money, January 22.

Laeven, L. and Valencia, F. (2008). Systemic Banking Crises: A New Database. IMF Working Paper 08/224, September, p. 80.

Laeven, L. and Valencia, F. (2010). Resolution of Banking Crises: The Good, the Bad, and the Ugly. IMF Working Paper No. 10/146, June 2010, p.36.

Lamprecht, J. (2002). "South Africa Is Quietly Collapsing", Rense.com, www.AfricaCrisis.Org, February 14, http://www.rense.com/general20/sa.htm[06/08/2011 21:41:50].

Lutz, S. (2000). Beyond the Basel Accord: Banking regulation in a system of multiple governance, International Studies Association, 41st Annual Convention, Los Angeles, CA, March 14-18.

Macheka, T. (2011). "Banks hit back", The Zimbabwe Situation, http://www.theindependent.co.zw/, Thursday, 02 June 2011 19:27, and http://www.zimbabwesituation.com/jun3a_2011.html. Accessed 08/06/2011.

Maiko, D. (2003). Euro Bank collapse: a tip of the iceberg? News From Africa: Archive / Kenya New Era / Analysis.

http://www.newsfromafrica.org/newsfromafrica/articles/art_1281.html. March.

Makhubela, S. (2006). "Causes of bank failure in the post democratic south Africa", MBA Dissertation, Graduate School of Business, University of KwaZulu-Natal, Unpublished

Mambondiani, L. (2011). “RMB collapse: a failure of regulation”, Posted On June 17, @ 14:18 In Money, Personal Finance, http:/ / www.newzimbabwe.com/blog/index.php/2011/06/Imambondiani/rbmcollapse-, Accessed 22/06/2011.

Mora, J. And Powers, W.M. (2009). “Decline and gradual recovery of global trade financing: US and global perspectives", Did trade credit problems deepen the great trade collapse? VOX- Research-based policy analysis and commentary from leading economists. http:/ / www.voxeu.org/index.php?q=node/4298. 27 November.

Mpofu, B. and Nyakazeya, P. (2011). "ReNaissance Bank placed under curatorship", The Zimbabwe Situation, http:/ /www.theindependent.co.zw/, Thursday, 02 June 2011 20:55, and http://www.zimbabwesituation.com/jun3a_2011.html. Accessed $08 / 06 / 2011$.

Muleya, D. (2008). “Zimbabwe: Banks Face Collapse”, Palapye.com News Blog, 26 January, http:/ / palapye.wordpress.com/2008/01/26/zimbabwe-banks-face-collapse/ Accessed 19/05/2011

Muleya, D. (2011). "Rescue plan for ailing banks in the offing - Biti", The Zimbabwe Situation, http://www.theindependent.co.zw/, Thursday, 02 June 2011 20:50, and http://www.zimbabwesituation.com/jun3a_2011.html. Accessed 08/06/2011.

Murphy, B.M. (2009). "Nigerian Banks Collapse - Could Affect USA", www.globalresearch.ca/index.php?context=va\&aid=15058. Accessed 12/07/2011. 
Nyakazeya, P. (2011). “Biti accuses banks of 'stealing', Published On: Tuesday, May 24, 12:07 PM GMT, http://www.newzimbabwe.com/news/news.aspx?newsID=5192.

Reinhart, C. and Rogoff, K. (2008). This Time is Different: A Panoramic View of Eight Centuries of Financial Crises. NBER Working Paper No. 13882, March, p.125.

Reinhart, C. M. and Rogoff, K.S. (2009). This Time Is Different: Eight Centuries of Financial Folly. Princeton University Press, p.496.

Robertson, J. (2011). As in Chimhangwa, K. (2011). “Zimbabwe banking sector struggles to survive". http://www.thestandard.co.zw/. Sunday, 01 May, 15:52.

Sandu, N. (2011). "How things got messy for ReNaissance", Sunday, 15 May, 14:08, http:/ / www.thestandard.co.zw/business/29722-how-things-got-messy-forrenaissance, Accessed 17/05/2011.

SearchSecurity, (2008). Basel II, SearchSecurity.co.uk. http:/ / searchsecurity.techtarget.co.uk/definition/Basel-II?vgnextfmt=print. Accessed 06/07/2011. 11Jan.

Swaziland Commentary, (2010). "The Government's Economic Crisis", Information and commentary about the struggle for democracy in the African Kingdom of Swaziland, Wednesday, December 15.

http:/ / swazilandcommentary.blogspot.com/2010/12/governments-economiccrisis.html Accessed 23/07/2011.

The Standard, (2011). "World Bank boss speaks on Zimbabwe", Sunday, 15 May, 13:28. http:/ / www.thestandard.co.zw/business/29714-world-bank-boss-speaks-onzimbabwe, Accessed 17/05/2011. 


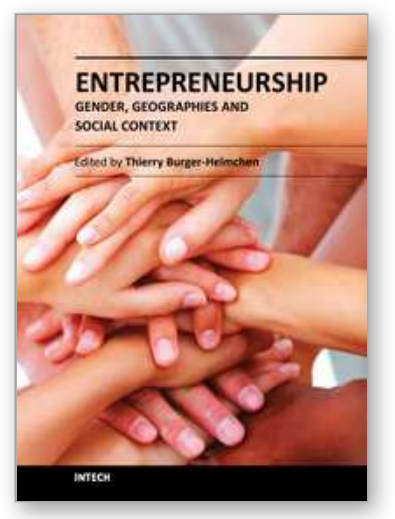

\author{
Entrepreneurship - Gender, Geographies and Social Context \\ Edited by Prof. Thierry Burger-Helmchen
}

ISBN 978-953-51-0206-9

Hard cover, 306 pages

Publisher InTech

Published online 14, March, 2012

Published in print edition March, 2012

Entrepreneurship is a main driver of economic growth and of social dynamics. However, some basic characteristics like the gender of the entrepreneur, the geographical location, or the social context may have a tremendous impact on the possibility to become an entrepreneur, to create a firm and to prosper. This book is a collection of papers written by an array of international authors interested in the question of entrepreneurship from a gender point of view (male vs female entrepreneurship), a geographical point of view (Africa, Europe, America and Latin America, Asia...) or a specific social context point of view (agricultural economy, farming or family business, etc.).

\title{
How to reference
}

In order to correctly reference this scholarly work, feel free to copy and paste the following:

Paul Stanford Kupakuwana (2012). Sustainable Retail Banking and Asset Management: Lessons from Challenges Faced by Entrepreneurs in African Economies, Entrepreneurship - Gender, Geographies and Social Context, Prof. Thierry Burger-Helmchen (Ed.), ISBN: 978-953-51-0206-9, InTech, Available from: http://www.intechopen.com/books/entrepreneurship-gender-geographies-and-social-context/sustainable-retailbanking-and-asset-management-lessons-from-challenges-faced-by-entrepreneurs-in-af

\section{INTECH}

open science | open minds

\section{InTech Europe}

University Campus STeP Ri

Slavka Krautzeka 83/A

51000 Rijeka, Croatia

Phone: +385 (51) 770447

Fax: +385 (51) 686166

www.intechopen.com

\section{InTech China}

Unit 405, Office Block, Hotel Equatorial Shanghai

No.65, Yan An Road (West), Shanghai, 200040, China

中国上海市延安西路65号上海国际贵都大饭店办公楼 405 单元

Phone: +86-21-62489820

Fax: $+86-21-62489821$ 
(C) 2012 The Author(s). Licensee IntechOpen. This is an open access article distributed under the terms of the Creative Commons Attribution 3.0 License, which permits unrestricted use, distribution, and reproduction in any medium, provided the original work is properly cited. 